\title{
Evaluation of Liver Function Test in Normal Pregnancy and Pre- eclampsia: A Case Control
}

\author{
Dr. Swapan Das ${ }^{1}$, Dr. Debasish Char ${ }^{1}$, Dr. Sanjay Sarkar ${ }^{2}$, \\ Dr. Tushar Kanti Saha ${ }^{3}$, Dr. Sucheta Biswas ${ }^{4}$, Dr. Biswapratim Rudra ${ }^{5}$ \\ ${ }^{1}$ (RMO, Dept. of Gynaecology and Obstetrics, Bankura Sammilani Medical College \& Hospital, Bankura); \\ ${ }^{2}$ (RMO, Dept. of Medicine, Bankura Sammilani Medical College \& Hospital, Bankura); ${ }^{3}$ (Asst. Prof., Dept. Of \\ Community Medicine, NRS Medical College, Kolkata); ${ }^{4}$ (PGT, Dept. of Physiology, Barddhaman Medical \\ College \& Hospital, Barddhaman); ${ }^{5}$ (Senior Resident, Dept. of Gynaecology and Obstetrics, Bankura \\ Sammilani Medical College \& Hospital, Bankura)
}

\begin{abstract}
:
Background and Objective: Preeclampsia is a multi system disorders that can affect every maternal organ predominantly the cardio-vascular system, kidneys, brain and liver. The present study was conducted to compare the liver function tests in preeclampsia with normotensive pregnancy. Methodology: The present case control study was carried out at the department of obstetrics and gynaecology of Bankura Sammilani Medical College, Bankura to find the serum bilirubin and serum levels of liver enzymes ALT, AST and ALP in 100 pregnant women (50 preeclampsia and 50 normotensive pregnant women). Results: The mean BMI of cases was $28.02 \pm 3.67 \mathrm{~kg} / \mathrm{m}^{2}$ and that of control was $24.48 \pm 3.09 \mathrm{~kg} / \mathrm{m}^{2}$. The mean value of serum bilirubin in cases was $10.62 \pm 3.72 \mu \mathrm{mol} / \mathrm{L}$ and in control it was $7.81 \pm 2.37 \mu \mathrm{mol} / \mathrm{L}(p<0.001)$. The mean value of enzyme ALP in cases was $55.78 \pm 30.93 \mathrm{U} / \mathrm{L}$ and in control it was $15.21 \pm 3.40 \mathrm{U} / \mathrm{L}(p<0.001)$. The mean value of enzyme AST in cases was $40.58 \pm 10.75 \mathrm{U} / \mathrm{L}$ and in control it was $8.21 \pm 2.60 \mathrm{U} / \mathrm{L}(p<0.001)$. The mean ALP level of cases before delivery was 458.15 $\pm 241.68 \mathrm{U} / \mathrm{L}$ and in control it was 182.32 $\pm 64.72 \mathrm{U} / \mathrm{L}(p<0.001)$. Conclusion: Elevated levels of serum bilirubin and liver enzymes ALT, AST and ALP were found in preeclampsia cases.
\end{abstract}

Keywords: Liver function test, Pre-eclampsia

\section{Introduction}

Preeclampsia is a pregnancy specific disorder that presents major health problems for both mothers and babies. It is defined as pregnancy specific syndrome observed usually after $20^{\text {th }}$ week of gestation with systolic blood pressure $\geq 140 \mathrm{~mm}$ of $\mathrm{Hg}$ and diastolic blood pressure $\geq 90 \mathrm{~mm}$ of $\mathrm{Hg}$ accompanied by significant proteinuria with or without Oedema. Severe preeclampsia is associated with elevated blood pressure $\geq 160 \mathrm{~mm}$ $\mathrm{Hg}$ systolic or $\geq 110 \mathrm{~mm}$ of $\mathrm{Hg}$ diastolic, on two occasions atleast $6 \mathrm{hrs}$ apart, on bed rest; with proteinuria $\geq 5 \mathrm{gm}$ in $24 \mathrm{hrs}$ urine sample ; along with other symptoms such as headache, visual disturbances, hyperreflexia, epigastric or right upper quardant pain, vomiting, oliguria, impaired liver function and thrombocytopenia (HELLP Syndrome) [1, 2]. Women with preeclampsia have persistent vasoconstriction due to an increased vascular responsiveness to physiologic vasoconstrictive agents such as angiotensin II or an increase in vascular tone or reactivity $[3,4]$.

Abnormalities in liver function test (LFT) occur in 3\% of pregnancies and preeclampsia is the most frequent cause [5]. Liver dysfunction in preeclampsia has grave consequences. In preeclampsia accompanied by HELLP syndrome, an elevation in liver enzymes such as Alanineaminotransferase (ALT) and Aspartateaminotransferase (AST) levels are noted and hyper billirubinemia may occur, especially in the presence of haemolysis. Parenchymal necrosis of liver causes elevation in hepatic enzymes. There may be subcapsular hematoma formation, eventually liver may rupture to cause sudden hypotension due to haemoperitoneum [6]. The objective of our present study was to compare liver function test in normotensive pregnancy and in preeclampsia.

\section{Materials \& Methods}

This case control study was conducted in obstetrics and gynaecology department of Bankura Sammilani Medical College, Bankura. In this study 100 pregnant women of 18 to 35 yrs of age were selected and were divided into two groups. Group - I (cases) had 50 cases of preeclampsia having BP $\geq 140 / 90 \mathrm{~mm}$ of $\mathrm{Hg}$, proteinuria $\geq 300 \mathrm{mg}$ in $24 \mathrm{hrs}$ urine sample and oedema. Group - II (control) included 50 pregnant women with normal BP after 20 weeks of gestation. The cases and controls having past history of renal diseases, liver diseases, diabetes, cardiac diseases, and history of drug intake that affects the liver function were excluded from the study. 
Serum bilirubin levels and plasma levels of liver enzymes ALT, AST, ALP were measured for all cases and controls. All data were expressed as mean \pm SD. Statistical analysis was carried out by t-test using SPSS-10 software.

\section{Results}

Body mass Index (BMI) of cases and controls were shown in Table -1 . The mean BMI of cases was $28.02 \pm 3.67$ and controls was $24.48 \pm 3.09$. The difference in the mean values of the two groups was highly significant $(\mathrm{p}<0.001)$.

Blood pressure of cases and controls were shown in Table -2 . The mean systolic BP of cases was $164.58 \pm 22.04 \mathrm{~mm}$ of $\mathrm{Hg}$ and of the controls was $114.72 \pm 8.01 \mathrm{~mm}$ of $\mathrm{Hg}(\mathrm{p}<0.001)$ The mean diastolic BP of cases was $104.48 \pm 12.16 \mathrm{~mm}$ of $\mathrm{Hg}$ and of the controls was $72.41 \pm 6.28 \mathrm{~mm}$ of $\mathrm{Hg}(\mathrm{p}<0.001)$.

Liver functions of cases and controls were shown in table -3 . The mean value of serum bilirubin in cases was $10.62 \pm 3.72 \mu \mathrm{mole} / \mathrm{L}$, and in controls it was $7.81 \pm 2.37 \mu$ mole $/ \mathrm{L}(\mathrm{p}<0.001)$. The mean value of enzyme ALT in cases was $55.78 \pm 30.93 \mathrm{U} / \mathrm{L}$ and in controls it was $15.21 \pm 3.40 \mathrm{U} / \mathrm{L}(\mathrm{p}<0.001)$. The mean values of serum AST in cases was $40.58 \pm 10.75 \mathrm{U} / \mathrm{L}$ and in the controls it was $8.21 \pm 2.60 \mathrm{U} / \mathrm{L}(\mathrm{p}<0.001)$. ALP levels of cases before delivery was $458.15 \pm 241.68 \mathrm{U} / \mathrm{L}$ and in the controls it was $182.32 \pm 64.72 \mathrm{U} / \mathrm{L}(\mathrm{p}<0.001)$.

\section{Discussion}

Preeclampsia is a multisystem pregnancy specific disorder that can affect almost every maternal organ, predominantly the vascular, renal, hepatic, cerebral and coagulation system [1,2,7]. High BMI before pregnancy has been seen to increase the risk of developing preeclampsia [2,8]. In our present study the preeclamptic patients had a significantly higher BMI compare to the women with normotensive pregnancy $(\mathrm{p}<0.001)$. Hauger et al., in their studies also concluded that higher BMI is associated with an increase risk of developing preeclampsia [9,10]. In our study serum bilirubin level was found significantly higher $(p<0.001)$ in preeclamptic group than the control group. Jaleel et. al noted in their study that there was a highly significant rise in serum bilirubin, LDH and AST level in preeclamptic women compared to normotensive pregnant women [11]. In our study serum ALT was significantly $(p<0.001)$ raised in preeclamptic women compared to the women with normotensive pregnancy. Several studies also had found a raised level of ALT in preeclamptic women which supports the findings of our present study [12]. In the present study the mean serum AST level in preeclamptic subjects was found significantly higher $(p<0.001)$ than the normotensive pregnant counterparts. And elevated level in AST in preeclampsia was also cited by some other authors [13, 14]. Rath et. al also found raised level of ALT and AST in severe preeclampsia [15].

\section{Conclusion}

Elevated level of serum bilirubin and hepatic enzymes ALT, AST and ALP were seen in preeclampsia cases.

\section{Reference}

[1]. National High Blood Pressure Education Program. Working Group on High Blood Pressure in Pregnancy. Report of the National High Blood Pressure Education Program. Working Group on High Blood Pressure in Pregnancy. Am J Obstet Gynecol 2000; 183(1):S 1-22.

[2]. ACOG Committee on Obstetric Practice. ACOG practice bulletin. Diagnosis and management of preeclampsia and eclampsia. Obstet Gynecol 2002;99(1): 159-67.

[3]. Kwiatowski S, Kwiatkowska E, Czajka R, Ciechanowski K, Kedzierska K, Bober J, et al. The activity of erythrocyte sodium-proton exchanger in women with pregnancy-induced hypertension. Hypertens Pregnancy 2006;25(1):37-46.

[4]. Lenfant C; National Education Program Working Group on High Blood Pressure in Pregnancy. Working Group Report on High blood pressure in pregnancy. J Clin Hypertens (Greenwich) $2001 ; 3(2): 75-88$.

[5]. Angel Gracia AL. Effect of pregnancy on pre-existing liver disease Physiological changes during pregnancy. Ann Hepatol 2000;5(3): 184-6.

[6]. Simith LG Jr, Moise KH Jr, Dildy GA III, Carpenter RJ Jr. Spontaneous rupture of liver during pregnancy: current therapy. Obstet Gynecol 1991;77:171-5.

[7]. Lopez-Jaramillo P. Casas JP, Serrano N. Preeclampsia: from epidemiological observation to molecular mechanism. Broz J Med Biol Res $2001 ; 34(10): 1227-35$.

[8]. Kaaja R. Predictors and risk factors of preeclampsia. Minerva. Gynecol 2008;60(5):421-9.

[9]. Hauger MS, Gibbons L, Vik T, Belizan JM. Pregnancy weight status and risk of adverse pregnancy outcome. Acta Obstet Gynecol Scand2008;87(9):453-9.

[10]. Noreen A, Rana G. Women with pregnancy induced hypertension: epidemiological difference between normotensive pregnant women. Professional Med J 2006; 13(2):310-2.

[11]. Jaleel A, Baseer A, Aamir S. Biochemical parameters for detection of hemolysis in pregnancy induced hypertensive women. J Coll Physicians Surg Pak 1999;9( 1 ):41 -2.

[12]. Knapen MF, Mulder TP, Bisseling JG, Penders RH, Peters WH, Steegers EA. Plasma glutathione-s-Transferase Alpha-1-1. A more sensitive marker for hepatocellular damage than serum alanine aminotransferase in hypertensive disorder of pregnancy. Am $\mathrm{J}$ Obstet Gynecol 1998;178(1): 161—5.

[13]. Mahmoudi N, Graves SW, Solomon CG, Repke JT, Seely EW. Eclampsia: A 13-year experience at a United States tertiary care Centre. J Womens Health Gender Base Med 1999;8:495-500. 
[14]. Haddad B, Barton JR, Livingston JC, Chahine R, Sibai BM. Risk factors for adverse maternal out comes among women with HELLP (hemolysis, elevated liver enzymes and low platelet count) Syndrome. Am J Obstet Gynecol 2000; 183:444-8.

[15]. Rath W, Faridi A, Dudenhausen JW. HELLP Syndrome. J Perinat Med 2000;28(4):249-60.

Table - 1: Body mass index of cases and controls

\begin{tabular}{|l|l|l|l|}
\hline Parameter & Cases & Controls & 'p' - value \\
\hline $\begin{array}{l}\text { BMI Kg } / \mathrm{m}^{2} \\
\text { Mean } \pm \text { SD }\end{array}$ & $28.02 \pm 3.67$ & $24.48 \pm 3.09$ & $<0.001$ \\
\hline
\end{tabular}

Table - 2: Blood Pressure of cases and controls

\begin{tabular}{|l|l|l|l|}
\hline Parameter & Cases & Controls & $\begin{array}{c}\text { 'p' } \\
\text { value }\end{array}$ \\
\hline $\begin{array}{l}\text { Systolic BP }(\mathrm{mm} \text { of } \mathrm{Hg}) \\
\text { Mean } \pm \text { SD }\end{array}$ & $164.58 \pm 22.04$ & $114.72 \pm 8.01$ & $<0.001$ \\
\hline $\begin{array}{l}\text { Diastolic BP }(\mathrm{mm} \text { of } \mathrm{Hg}) \\
\text { Mean } \pm \text { SD }\end{array}$ & $104.48 \pm 12.16$ & $72.41 \pm 6.28$ & $<0.001$ \\
\hline
\end{tabular}

Table - 3: Liver function of cases and controls

\begin{tabular}{|l|l|l|l|}
\hline Parameter & Cases & Controls & 'p' - value \\
\hline $\begin{array}{l}\text { Serum Bilirubin }(\mu \text { mole } / \text { Ltr) } \\
\text { Mean } \pm \text { SD }\end{array}$ & $10.62 \pm 3.72$ & $7.81 \pm 2.37$ & $<0.001$ \\
\hline $\begin{array}{l}\text { ALT }(\text { U/L) } \\
\text { Mean } \pm \text { SD }\end{array}$ & $55.78 \pm 30.93$ & $15.21 \pm 3.40$ & $<0.001$ \\
\hline $\begin{array}{l}\text { AST ( U/L) } \\
\text { Mean } \pm \text { SD }\end{array}$ & $40.58 \pm 10.75$ & $8.21 \pm 2.60$ & $<0.001$ \\
\hline $\begin{array}{l}\text { ALP }(\text { U/L) } \\
\text { Mean } \pm \text { SD }\end{array}$ & $458.15 \pm 241.68$ & $182.32 \pm 64.72$ & $<0.001$ \\
\hline
\end{tabular}

